\title{
CONSUMER PERCEPTION ON SENSORY ATTRIBUTES OF SELECTED LOCAL INDONESIAN COFFEE
}

\author{
ANANDYA VANESSA ISNIDAYU*, ANGGORO CAHYO SUKARTIKO \\ and MAKHMUDUN AINURI \\ Department of Agro-industrial Technology, Faculty of Agricultural Technology, \\ Universitas Gadjah Mada, Bulaksumur, Yogyakarta 55281, Indonesia \\ *E-mail: anandyavanessa@yahoo.com
}

Accepted 4 September 2020, Published online 25 October 2020

\begin{abstract}
The increase in coffee consumption for the last few years, especially for specialty coffee, becomes an opportunity to develop the local coffee market in Indonesia. In terms of developing local coffee, consumers' sensory quality knowledge plays a vital role for coffee producer and marketer to increase sales. Taking this fact into account, the purpose of this study was to establish the quality of the sensory attributes of two selected local Indonesian coffee grown in Cianjur and Pangalengan, West Java. This study also aims to determine consumer perceptions of the attributes. Quality of the sensory attributes was evaluated by three certified panelists from the Indonesian Coffee and Cocoa Research Institute using cup testing method according to Specialty Coffee Association of America (SCAA) standard, while consumer perception was studied based on gap analysis between perceived importance and performance of the sensory attributes, assessed by 35 participants. Result revealed that the coffees had passed specialty grade and customer satisfaction, indicating the great potential for their market development. However, improvements in several sensory attributes such as flavour, aftertaste, and balance still need to be done.
\end{abstract}

Key words: Indonesian coffee, coffee attributes, roasting level, brewing technique

\section{INTRODUCTION}

Coffee is the main tropical commodity traded throughout the world. As a tropical country, Indonesia is a suitable location for coffee cultivation. In 2018, Indonesia ranked fourth as the world's coffee producer after Brazil, Vietnam, and Colombia (International Coffee Organization, 2019). Meanwhile, the consumption growth of the coffee product in Indonesia has increased by an average of 7\% per year (Ministry of Industry of the Republic of Indonesia, 2016). This growth is driven by Indonesia's expanding middle class and their growing taste for coffee (Wright \& Rahmanulloh, 2017). This growing taste increases the demand for specialty coffee that becomes an opportunity to develop the local coffee market (Purnomo, 2018).

West Java is one of the local coffee producing areas in Indonesia. The coffee has known to be exported to South Korea, Morocco, Taiwan, Hongkong, China, Japan, England, Netherland, and

* To whom correspondence should be addressed.
Germany (Putra \& Ferry, 2015). In 2013, the Indonesian Ministry of Law and Human Rights had certified local coffee products from several regions in West Java as a Geographical Indication (GI) product under the name of Java Preanger Arabica Coffee (Directorate General of Intellectual Property, 2016). Furthermore, the development of local coffee has not only stopped on the certified coffees, but also has been carried out on other potential local coffees, one of which is local coffee originating from Cianjur District. Cianjur was once an export coffee supplier area, especially Arabica, and is currently redeveloping the potential of its local coffees, involving farmers and marketers.

Marketers have a great interest in socializing coffee sensory attributes to consumers with the aim of increasing sales (Li et al., 2019). However, research on sensory quality of local coffee are still limited. In general, the assessment of coffee sensory attributes is carried out by trained panelists using cup testing conforming to the Specialty Coffee Association of America (SCAA) standard (SCAA, 2015). Taking into account that consumer 
perceptions are very important for the food industry to create products that meet consumer expectations, analysis of consumer perception of the sensory attributes is also essential.

Previous study concluded that quality of sensory attributes could be manipulated through the roasting level, considering the flavour and aroma characteristics will be formed from thermal reactions that occur during the roasting process (Sunarharum et al., 2014). In addition to roasting level, brewing technique also affects coffee sensory attributes. Some sensory attributes that may differ significantly because of the dissimilar treatment in brewing technique were the aroma, bitter taste, acidity, aftertaste, and body (Fibrianto et al., 2018). On that basis, the present study is aimed to determine the sensory attributes of selected local Indonesian coffees in relation to consumer perception and further insights in determining the appropriate roasting levels and brewing techniques to improve the sensory quality of local coffee.

\section{MATERIALS AND METHODS}

Two types of local coffee originating from the West Java region were chosen as samples, each representing 'certified' and 'not yet certified' as a GI product that possess qualities that are attributable to a specific geographical origin (World Intellectual Property Organization, 2017). Based on Government Regulation of the Republic of Indonesia Number 51 Year 2007 on Geographical Indication, GI means a sign that shows the area of origin of goods, which is due to environmental factors including geographical and human factors, or the combination of these two factors, gives a characteristic and certain quality of the produced goods (Indonesian Government, 2007). From all Java Preanger GI regions, Pangalengan is one of the subdistricts with the largest growing area and yield. Therefore, local coffee from Pangalengan was chosen to represent certified products, whereas local coffee from Cianjur was used to represent coffee that does not have certification yet.

The coffee sample was taken purposively from its area of origin at an altitude range of 1000 to 1500 masl. The region in that altitude range is categorized very suitable for the growth of Arabica coffee plants (Directorate General of Plantation, 2014). According to Hill (1998) the ideal number of samples in this study is 30 to 500 samples. Based on this, 30 coffee trees were chosen to take random bean samples. The coffee was prepared by full wash process. Three hundred gram samples of green coffee beans were roasted at medium level with a temperature of $200-210^{\circ} \mathrm{C}$ for $18 \mathrm{~min}$ and stored for
$24 \mathrm{hr}$ in impermeable bags at room temperature to be used as samples for sensory evaluation.

The evaluation was carried out using cup testing method according to the SCAA protocols for specialty coffee by three certified panelists from the Indonesian Coffee and Cocoa Research Institute. Roasted coffee beans were ground with 20 mesh sieve. The dry aroma of the samples was evaluated within $15 \mathrm{~min}$ after grinding. Five cups from each sample were prepared to evaluate sample uniformity. The coffee was brewed using $8.25 \mathrm{~g}$ of grounded coffee per $150 \mathrm{~mL}$ of water $\left(\mathrm{T}=93^{\circ} \mathrm{C}\right)$. The hot water was poured directly onto the grounds to the rim of the cup and allowed to stand for four minutes of extraction before evaluation. The wet evaluation of aroma was done by sniffing the foam. Flavour and aftertaste were rated after the samples had cooled to $71^{\circ} \mathrm{C}$. Acidity, body, and balance were rated next at $65^{\circ} \mathrm{C}$, while sweetness, uniformity, and clean cup were rated at $35^{\circ} \mathrm{C}$. The panelists assessed each attribute with a score of 6.00 to 6.75 (good), 7.00 to 7.75 (very good), 8.00 to 8.75 (excellent), and 9.00 to 9.75 (outstanding). The score of all attributes was summed to get the final score. The minimum value required for specialty grade is 80.00 (SCAA, 2015).

For the consumer perception analysis, consumer sampling was done purposively with snowball technique by asking a few consumers who qualify to be participants and recruit future participants among their acquaintance until data saturation. Connoisseur's consumers of both Java Preanger and Cianjur coffee who possess awareness of the sensory quality and knowledge of sensory attribute terms of coffee were chosen as participants. Because the samples with the target characteristics are not easily accessible, the minimum number of sample size determined in this study was 30 (Patton, 1990). Data collection was conducted by a survey using a valid and reliable questionnaire with the Cronbach's Alpha value of 0.816 . The participants were asked to rate their perceived importance and performance of sensory attributes using a seven-point Likert scale anchored with $1=$ Strongly Unimportant and $7=$ Strongly Important for perceived importance, and $1=$ Strongly Dissatisfied and $7=$ Strongly Satisfied for perceived performance of sensory attributes. Eight sensory attributes were evaluated, such as aroma, flavour, aftertaste, acidity, body, balance, sweetness and clean cup. Uniformity attribute was not used in the consumer evaluation because the attribute assesses the consistency from several cups, whereas consumers generally only consume one cup at a time.

Analysis of consumer perceptions was conducted using gap analysis between perceived importance and performance of the attributes, also 
known as Importance-Performance Analysis (IPA). The study measures the suitability of product performance by identifying the importance of product attributes and how well the attributes are performed based on actual consumer perceptions (Lee, 2019). The mean value for performance and importance of each attribute were calculated to determine the gap. Paired sample t-tests were carried out to evaluate the gap, whether it had significant differences or not. The data was analyzed using SPSS version 23. To give a clearer depiction, each attribute was plotted in the IPA matrix and grouped into four quadrants. Quadrant 1 contains attributes that need improvement, quadrant 2 need to be maintained, quadrant 3 implying low priority attributes, and quadrant 4 implying the attributes are overly satisfied. There are different approaches for dividing the IPA matrix. In this study, an alternative IPA matrix was applied by adding a diagonal line to meet the cross-point of data-centered quadrants. The area above the diagonal line is considered as quadrant 1 . Greater distance from the diagonal line indicates a higher priority for improvement (Lee, 2019).

\section{RESULTS AND DISCUSSION}

\section{Participants demographic profile}

The number of participants involved in this study was 35 . Based on participant's recruitment using snowball sampling technique, 40 consumers were found but only 35 people met the target characteristics. This number, according to Patton (1990), meets the sample size criteria in snowball sampling. Most of the participants involved in this study were males (97\%), as most of coffee connoisseur's consumers are also males (Demura et al., 2013). A significant number of participants are young people aged between 17 to 25 years old (68\%). Literature review also showed a trend among young people to consume coffee because of its taste and its benefits as an energy drink (Hashim et al., 2017; Kelly \& Prichard, 2016). More than half $(52 \%)$ of the participants were private employees. Majority of the participants $(82 \%)$ had monthly income above the regional minimum wage. Based on their coffee habit, $80 \%$ of participants consumed coffee regularly. Among those who drink coffee regularly, approximately $40 \%$ of the participants drank 1 to 3 cups per day. Others only drank a cup $(26 \%)$ and more than three cups of coffee per day (14\%). The participant's demographic profile mentioned previously indicates that connoisseur's consumers of Cianjur and Java Preanger coffee are upper-middle-class young people.

\section{Quality of sensory attributes}

Determination of sensory quality attributes was conducted using cup testing by trained panelists as one of the industrial standard measurements of coffee sensory quality (Sunarharum et al., 2014). Table 1 shows the result of cup testing. It was found that every attribute for both local coffee's scores were almost similar. Panelists noted a slight difference in flavour, aftertaste, acidity, body, and balance, where the Java Preanger receives higher scores. The previous study confirmed that coffee sensory attributes, especially flavour and acidity, were strongly influenced by temperature during seed development (Bertrand et al., 2012). Coffees grown under lower temperature conditions are more acidic and has a better flavour than those cultivated under warmer temperature (Bertrand et al., 2012). Based on climate data, the area of origin of the Java Preanger coffee sample has an average annual temperature of $17.72^{\circ} \mathrm{C}$, lower than the area of origin of the Cianjur coffee sample which has an average annual temperature of $21.2^{\circ} \mathrm{C}$ (Meteorological, Climatological, and Geophysical Agency, 2019). This climatic factor may cause differences in some sensory attributes in both coffee samples.

Based on the final score, Java Preanger and Cianjur coffee samples meet the minimum value for the specialty grade. This result indicates that both local coffees have the potential to be developed on a broader market. Through cup testing, panelists detected flavour with notes of brown sugar, spicy, lemony, fruity, honey, caramel, and black tea in Java Preanger, while herbal, caramel, spicy, and flowery detected in Cianjur coffee. The difference in the flavour notes can be influenced by genetic factors, environmental conditions, and processing system (Belay et al., 2016). Coffee planting in West Java

Table 1. Cup testing score for Java Preanger and Cianjur coffee assesed by three trained panelists

\begin{tabular}{lccccc}
\hline Attribute & Java Preanger & Cianjur & Attribute & Java Preanger & Cianjur \\
\hline Aroma & 8.00 & 8.00 & Balance & 7.88 & 7.75 \\
Flavour & 8.00 & 7.75 & Sweetness & 10.00 & 10.00 \\
Aftertaste & 7.75 & 7.50 & Clean cup & 10.00 & 10.00 \\
Acidity & 8.00 & 7.63 & Overall & 8.00 & 7.75 \\
Body & 7.88 & 7.75 & Taint/Defect & 0.00 & 0.00 \\
Uniformity & 10.00 & 10.00 & Final score & 85.50 & 84.13 \\
\hline
\end{tabular}


is generally carried out in forest and mountain areas under various types of shade plants. The shades will increase the accumulation of organic matter and also maintain relative soil moisture and temperature (De Beenhouwer et al., 2015). These conditions affect the process of mineralization and the availability of soil nutrients, which is an important factor that influences the chemical composition of coffee beans which further affects the flavour character of coffee (Yadessa et al., 2008).

The panelist also detected harsh characteristic in both coffee samples, which decreases the score of flavour and aftertaste that affects the balance. Harsh is described as pungent and disagreeable taste and could be in the form of bitterness. The appearance of this unwanted bitter taste can make it difficult for consumers to identify the flavour in coffee (Fibrianto et al., 2018).

\section{Consumer perception of coffee sensory attributes}

Consumer perception on sensory attributes of the coffee samples based on the gap analysis between perceived importance and performance were shown in Table 2. The attribute that has a higher mean score indicates a higher level of perceived importance or performance. Mean difference denotes the gap between importance and performance. Based on the result, there is no significant difference $(p>0.05)$ between the mean importance and performance of aroma, acidity, body, clean cup, and sweetness attributes. These insignificant differences indicate that these attributes have met consumer expectations.

The significant mean difference $(p<0.05)$ was observed in three attributes of both coffees, including flavour, aftertaste, and balance. These three attributes had a negative mean difference because the mean performance was still lower than mean importance. These results indicate that although both coffee products meet the minimum values for specialty grade, efforts still need to be done to improve the performance of sensory attributes, specifically flavour, aftertaste, and balance, in order to meet consumer expectations.

Figure 1 depicts the distribution of eight sensory attributes on the alternative IPA matrix. Five sensory attributes were located in quadrant 1 "Concentrate here" including flavour, aftertaste, acidity, body, and balance. Based on the distance from the diagonal line, balance, aftertaste, and flavour need higher priority for improvement. This result is in accordance with a gap analysis, showing that those attributes have significant negative mean differences between importance and performance.

\section{Determining the appropriate level of roasting and brewing technique}

The findings of this study suggest priority improvement in flavour, aftertaste, and balance attributes. The flavour is a combination of the taste and aroma of brewed coffee. Based on the results of consumer preference analysis, aroma attribute had

Table 2. Gap analysis between perceived importance and performance for Cianjur and Java Preanger coffee sensory attributes

\begin{tabular}{|c|c|c|c|c|c|c|c|}
\hline \multirow{2}{*}{ Sensory attribute } & \multicolumn{2}{|c|}{ Importance } & \multicolumn{2}{|c|}{ Performance } & \multirow{2}{*}{$\begin{array}{c}\text { Mean } \\
\text { difference }\end{array}$} & \multirow{2}{*}{ t-value } & \multirow{2}{*}{$p$-value } \\
\hline & Mean & SD & Mean & SD & & & \\
\hline \multicolumn{8}{|l|}{ Cianjur } \\
\hline 1. Aroma & 5.80 & 1.18 & 5.43 & 1.22 & -0.37 & -1.81 & 0.079 \\
\hline 2. Flavour & 6.14 & 0.97 & 5.40 & 1.24 & -0.74 & $-3.53^{* *}$ & 0.001 \\
\hline 3. Aftertaste & 6.20 & 0.68 & 5.43 & 1.38 & -0.77 & $-3.32^{* *}$ & 0.002 \\
\hline 4. Acidity & 5.34 & 1.61 & 4.69 & 1.66 & -0.66 & -1.93 & 0.062 \\
\hline 5. Body & 5.51 & 1.20 & 5.00 & 1.48 & -0.51 & -1.97 & 0.057 \\
\hline 6. Balance & 6.17 & 0.98 & 5.31 & 1.28 & -0.86 & $-4.55^{* *}$ & 0.000 \\
\hline 7. Sweetness & 5.17 & 1.71 & 5.34 & 1.28 & 0.17 & 0.53 & 0.597 \\
\hline 8. Clean cup & 5.26 & 1.31 & 5.40 & 1.09 & 0.14 & 0.52 & 0.603 \\
\hline \multicolumn{8}{|l|}{ Java Preanger } \\
\hline 1. Aroma & 5.80 & 1.18 & 5.54 & 0.85 & -0.26 & -1.16 & 0.255 \\
\hline 2. Flavour & 6.14 & 0.97 & 5.66 & 0.80 & -0.48 & $-2.51^{*}$ & 0.017 \\
\hline 3. Aftertaste & 6.20 & 0.68 & 5.17 & 1.32 & -1.03 & $-4.62^{* *}$ & 0.000 \\
\hline 4. Acidity & 5.34 & 1.61 & 5.14 & 1.38 & -0.20 & -0.85 & 0.400 \\
\hline 5. Body & 5.51 & 1.20 & 5.09 & 1.29 & -0.43 & -1.69 & 0.100 \\
\hline 6. Balance & 6.17 & 0.98 & 5.31 & 1.02 & -0.86 & $-5.37^{* *}$ & 0.000 \\
\hline 7. Sweetness & 5.17 & 1.71 & 5.14 & 1.17 & -0.03 & -0.09 & 0.930 \\
\hline 8. Clean cup & 5.26 & 1.31 & 5.43 & 0.88 & 0.17 & 0.68 & 0.499 \\
\hline
\end{tabular}

Mean $(\mathrm{N}=35)$. t-test two tailed with probability ${ }^{\star} p<0.05$ and ${ }^{* \star} p<0.01$. SD: standard deviation. 


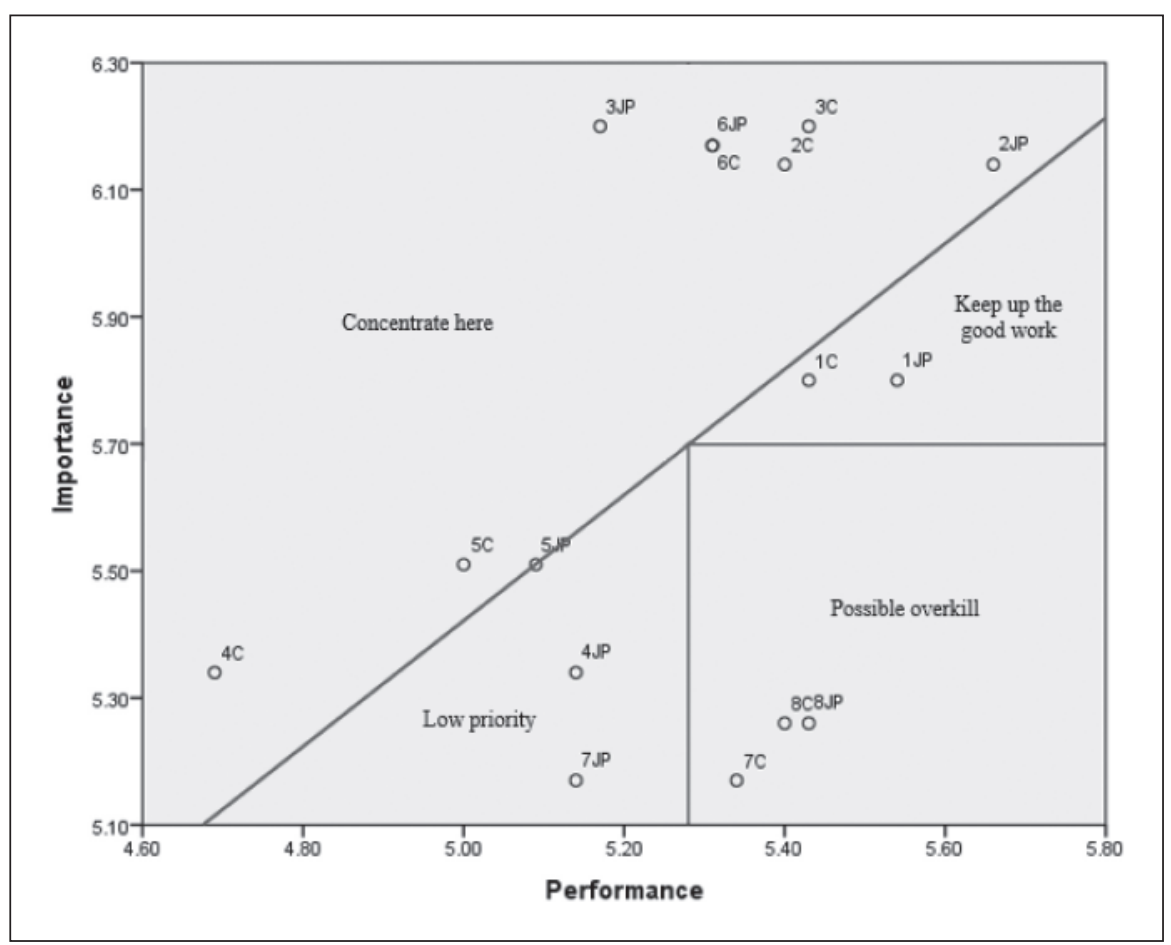

Fig. 1. IPA matrix.

met consumer satisfaction, that can be seen from the gap performance that is not significantly different and its position in quadrant 2 "Keep up the good work" in the IPA matrix. Thus, the perceived performance of flavour attribute that has not met its perceived importance may be influenced by taste factors. This proposition is supported by the identification of harsh character in cup testing. This character is thought to reduce perceived performance scores of flavour, aftertaste and balance attributes. Although this flavour character may already be present in coffee beans, the roasting process could control the developmental progress of the flavour compound (Bhumiratana et al., 2011). According to Kipkorir et al. (2015), the bitterness appeared due to the formation of furan compound. This compound is generated by the Maillard reaction, which is enhanced with the length of roasting (Van Lancker et al., 2011). In this study, the roasting time used was $18 \mathrm{~min}$. Giacalone et al. (2019) reported that lightly roasted coffee (4 minutes earlier than medium roast) was significantly lower in bitter characteristic. However, the use of this roasting level can reduce the performance of aroma attributes since shorter roasting time prevented full aroma development. Therefore, the application of roasting levels between light and medium is recommended.

In addition to the roasting level, brewing technique plays a role in translating coffee flavour from the ground coffee into the beverage for consumption (Sunarharum et al., 2014). Ludwig et al. (2012) reported that longer time and higher water temperature used in extraction in the brewing process would increase the content of dissolved compounds in coffee. Basically, compounds that generate the sour taste is extracted first, followed by the sweet and bitter. In other words, the bitter taste tends to be more intense as the extraction processes (Fibrianto et al., 2018). In this study, the extraction time used was 4 min. To prevent an excessive bitter taste, barista is suggested using a shorter extraction time.

\section{CONCLUSION}

The results of this study conclude that two local coffees from West Java used in this study have met the specialty grade and customer satisfaction. It was found that every attribute for both local coffees scores were almost similar based on assessment of trained panelists and consumers, indicates that the sensory quality of Cianjur coffee is as good as the Java Preanger coffee which has already had a reputation because of its GI certification. Through cup testing, panelists detected flavour with notes of brown sugar, spicy, lemony, fruity, honey, caramel, and black tea in Java Preanger, while herbal, caramel, spicy, and flowery detected in Cianjur coffee. However, improvements in several sensory attributes such as flavour, aftertaste, and balance still need to be done as the mean performance of those attributes were still lower than mean importance 
based on consumer evaluation. Studies relating to the effects of roasting levels and brewing techniques on the quality of sensory attributes need to be carried out by applying several treatments to find out the best roasting level and brewing technique for Cianjur and Java Preanger coffee.

\section{ACKNOWLEDGEMENTS}

The authors gratefully acknowledge the Indonesian Endowment Fund for Education (LPDP) for the scholarship and financial support to this work. We also thank the farmers, marketers, and consumers of local coffee in West Java for their assistance in collecting data.

\section{REFERENCES}

Belay, S., Mideksa, D., Gebrezgiabher, S. \& Seifu, W. 2016. Factors affecting coffee (Coffea Arabica L.) quality in Ethiopia: A review. Journal of Multidisciplinary Scientific Research, 4(1): 27-33.

Bertrand, B., Descroix, F., Boulanger, R., Berthiot, L., Ribeyre, F., Dussert, S. \& Joët, T. 2012. Climatic factors directly impact the volatile organic compund fingerprint in green Arabica coffee bean as well as coffee beverage quality. Food Chemistry, 135: 2575-2583

Bhumiratana, N., Adhikari, K. \& Chambers, E. 2011. Evolution of sensory aroma attributes from coffee beans to brewed coffee. LWT - Food Science and Technology, 44: 2185-2192.

De Beenhouwer, M., Muleta, D., Peeters, B., Van Geel, M., Lievens, B. \& Honnay, O. 2015. DNA pyrosequencing evidence for large diversity differences between natural and managed coffee mycorrhizal fungal communities. Agronomy for Sustainable Development, 35: 241-249.

Demura, S., Aoki, H., Mizusawa, T., Soukura, K., Noda, M. \& Sato, T. 2013. Gender differences in coffee consumption and its effects in young people. Food and Nutrition Science, 4: 748-757.

Directorate General of Intellectual Property. 2016. Registered geographical indications [WWW Document]. URL http://www.dgip.go.id/images/ ki-images/pdf-files/indikasi_geografis/ Permohonan $\% 20 y g \% 20$ Terdaftar $\% 20+\% 20$ LOGO\%20update\%20oktober.pdf (accessed 9.12.19)

Directorate General of Plantation. 2014. Good Agricultural Practices on Coffee. Ministry of Agriculture Republic Indonesia, Jakarta.
Fibrianto, K., Febryana, Y.R. \& Wulandari, E.S. 2018. Effect of brewing technique and particle size of the ground coffee on sensory profiling of brewed Dampit robusta coffee. IOP Conference Series: Earth and Environmental Science, 131: 012009.

Giacalone, D., Degn, T.K., Yang, N., Liu, C., Fisk, I. \& Münchow, M. 2019. Common roasting defects in coffee: Aroma composition, sensory characterization and consumer perception. Food Quality and Preference, 71: 463-474.

Hashim, N.H., Mamat, N.A., Nasarudin, N. \& Halim, N.A.A. 2017. Coffee culture among generation Y. Pertanika Journal of Social Sciences and Humanities, 25: 39-48.

Hill, R. 1998. What sample size is "enough" in internet survey research? Interpersonal Computing and Technology, 6:1-10.

Indonesian Government. 2007. Government Regulation of the Republic of Indonesia Number 51 of the Year 2007 regarding Geographical Indications. State Gazette of The Republic of Indonesia of 2007 Number 115. State Secretariat, Jakarta.

International Coffee Organization. 2019. Total production by all exporting countries. Retrieved on 2019, April 24 from: http://www.ico.org/ prices/po-production.pdf

Kelly, C.K. \& Prichard, J.R. 2016. Demographics, health, and risk behaviours of young adults who drink energy drinks and coffee beverages. Journal of Caffeine Research, 6(2): 73-81.

Kipkorir, R., Muhoho, S., Muliro, P., Mugendi, B., Frohme, M. \& Broedel, O. 2015. Effects of coffee processing technologies on aroma profiles and sensory quality of Ruiru 11 and SL 28 Kenyan Coffee varieties. Asian Journal of Agriculture and Food Sciences, 3(2): 2321-1571.

Lee, E. 2019. Indoor environmental quality (IEQ) of LEED-certified home: Importance-Performance Analysis (IPA). Building and Environment, 149: 571-581.

Li, J., Streletskaya, N.A. \& Gómez, M.I. 2019. Does taste sensitivity matter? The effect of coffee sensory tasting information and taste sensitivity on consumer preferences. Food Quality and Preference, 71: 447-451.

Ludwig, I.A., Sanchez, L., Caemmerer, B., Kroh, L.W., De Peña, M.P. \& Cid, C. 2012. Extraction of coffee antioxidants: Impact of brewing time and method. Food Research International, 48: 57-64.

Meteorological, Climatological, and Geophysical Agency. 2019. Average Temperature Data for 2014-2018 Period in Pacet District. BMKG Bogor Climatology Station, Cianjur. 
Ministry of Industry of the Republic of Indonesia. 2016. Menperin: Gaya hidup dorong industri kopi tumbuh [WWW Document]. URL http:// www.kemenperin.go.id/artikel/15421/ Menperin:-Gaya-Hidup-Dorong-IndustriKopiTumbuh (accessed 2.27.19).

Patton, M. 1990. Qualitative Evaluation and Research Methods. Sage Publications, California.

Purnomo, M. 2018. Contesting Indonesia's single origin coffee market: A dynamic capabilities perspective. Asian Social Science, 14(8): 91101.

Putra, S. \& Ferry, Y. 2015. Performance of Java Preanger Arabica coffee in West Java. Sirkuler Inovasi Tanaman Industri dan Penyegar, 3(3): 113-126.

SCAA. 2015. SCAA protocols cupping specialty coffee [WWW Document]. URL http://www. scaa.org/PDF/resources/cuppingprotocols.pdf (accessed 4.7.19).

Sunarharum, W.B., Williams, D.J. \& Smyth, H.E. 2014. Complexity of coffee flavour: A compositional and sensory perspective. Food Research International, 62: 315-325.
Van Lancker, F., Adams, A., Owczarek-Fendor, A., De Meulenaer, B. \& De Kimpe, N. 2011. Mechanistic insights into furan formation in maillard model systems. Journal of Agricultural and Food Chemistry, 59: 229-235.

World Intellectual Property Organization. 2017. Geographical indication: an Intoduction [WWW Document]. URL https:/www.wipo.int/edocs/ pubdocs/en/geographical/952/wipo_pub_ 952.pdf (accessed 9.12.19).

Wright, T. \& Rahmanulloh, A. 2017. Indonesia coffee annual report 2017 [WWW Document]. URL https://gain.fas.usda.gov/Recent GAIN Publications/Coffee Annual_Jakarta_Indonesia_5-15-2017.pdf (accessed 4.9.19).

Yadessa, A., Burkhardt, J., Denich, M., Woldemariam, T., Bekele, E. \& Goldbach, H. 2008. Influence of soil properties on cup quality of wild arabica coffee in coffee forest ecosystem of SW Ethiopia, in: 22nd International Conference on Coffee Science (ASIC). Campinas. 
